\author{
Corpus \\ 14 | 2015 \\ Constitution et usage de corpus en linguistique \\ berbère
}

\title{
Attrition and revival in Awjila BerberFacebook posts as a new data source for an endangered Berber language
}

Marijn van Putten and Lameen Souag

\section{(2) OpenEdition}

\section{Journals}

Electronic version

URL: http://journals.openedition.org/corpus/2593

ISSN: $1765-3126$

\section{Publisher}

Bases; corpus et langage - UMR 6039

\section{Printed version}

Date of publication: 1 January 2015

Number of pages: $23-58$

ISBN: 1 638-9808

ISSN: 1638-9808

\section{Electronic reference}

Marijn van Putten and Lameen Souag, "Attrition and revival in Awjila BerberFacebook posts as a new data source

for an endangered Berber language », Corpus [Online], 14 | 2015, Online since 28 August 2017, connection on 08 September 2020. URL : http://journals.openedition.org/corpus/2593

This text was automatically generated on 8 September 2020 .

(c) Tous droits réservés 


\title{
Attrition and revival in Awjila BerberFacebook posts as a new data source for an endangered Berber language
}

\author{
Marijn van Putten and Lameen Souag
}

\section{Introduction}

One of the smallest Berber languages of Libya is Awjili, spoken in Cyrenaica, about 350 $\mathrm{km}$ west of the Egyptian border ${ }^{1}$. Our knowledge of the language is limited to a few texts and wordlists, of which only Paradisi (1960a, b) is of much use; Van Putten (2014) analyses these to produce a grammar and wordlist with a new phonemic analysis. Despite its incompleteness, this material reveals that the language contains a lot of basic vocabulary unattested elsewhere in Berber, and falls outside of any of the dialect continua into which Berber may be divided (Kossmann 1999: 31), making its documentation all the more important. The new data discussed below indicates that Awjili is also seriously endangered, approaching Stage 7 of Fishman's (1991) 8-level Graded Intergenerational Disruption Scale.

After the rise to power of Gaddafi, linguistic work on Libyan Berber became nearly impossible. In 2011, Simone Mauri (pc) visited Awjila and found that the language was still spoken, but was unable to gather much data due to political difficulties. As of the time of writing, fieldwork remains too dangerous to be seriously contemplated. However, recently a good deal of linguistic data has become available in written form on the internet.

During the time of Gaddafi, Libyan Berbers were effectively made invisible: the state's position was that there were no minorities in Libya, and efforts to suggest otherwise risked severe punishment (Joffe 2014, Al-Rumi 2009). The Libyan revolution, in which the Berber towns of the Nefusa mountains and Zuwara in the northwest played a 
significant role, gave Berber identity sudden new prominence, expressed publicly through the creation of Berber-language mass media and schools. With $20 \%$ of the population Internet users (CIA 2013), an important forum for discussing this identity re-creation was inevitably Facebook. Facebook groups dedicated to Libyan Berber identity and/or language -usually writing in Arabic- were created in substantial numbers. Many were region-specific, but this trend did not affect only the "core" Berber-speaking regions of the northwest; Internet users of Awjila, among others, joined in enthusiastically.

On 19 February, 2012, just a few months after the end of the revolution, a number of Awjilis started a Facebook group named Ašal=ənnax ${ }^{2}$ (lit. 'our village'), with the slogan:

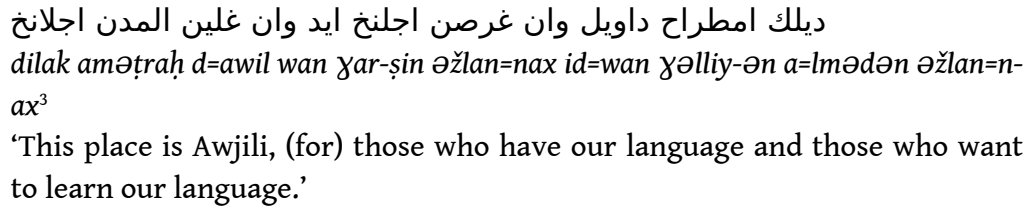

Over the next couple of years, they would use it to converse with each other in Awjila Berber (exchanging jokes, discussing politics, sharing news, and more), to challenge one another to identify obsolescent words, and to share lists of traditional vocabulary and stories. Their usage often shows major differences from the system described by Van Putten (2014) based on older sources. In particular, there are frequent signs of grammatical attrition

-not surprising, in view of users' modest assessment of their own language abilities and of their age-mates':

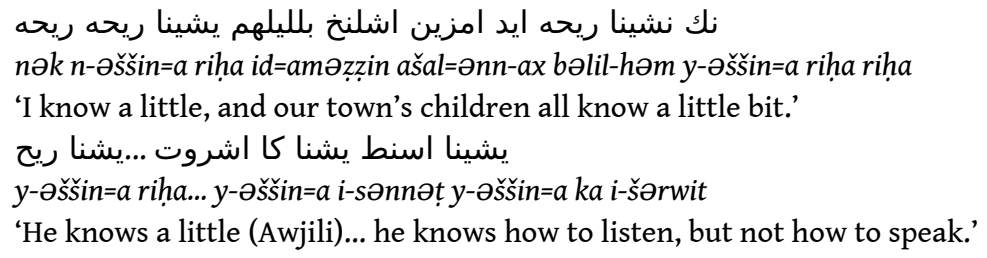

Founded slightly later, with the motto "You are Awjili, therefore you are Amazigh", the group Amazi Awjilah: Tmaziyt $n$ Tiniri ${ }^{4}$ (lit. "Amazigh of Awjila: Tamazight of the Desert") was primarily dedicated to general Amazigh issues, but made several postings on Awjili, giving wordlists and short phrasebooks. Its members comment on the state of the language, confirming the picture given by Ašal=ənnax:

نسوا اللغة 20الشباب دون السن

'Young people under 20 years have forgotten the language.' شيابين اوجله قاعدين يتكلمو بيها الى توا عندي صاحبي جده يتكلم بيها وبوه يفهم بس تسبن

'The elders of Awjila have continued to speak it up to now; my friend's grandmother speaks it, and his father only understands it.'

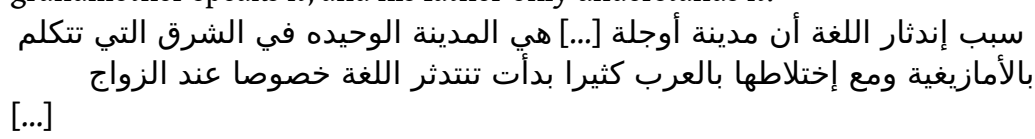

'The reason for its disappearance is that the town of Awjila [...] is the only town in the east which speaks Tamazight, and through its extensive contact with Arabs the language began to disappear, especially through marriage $[\ldots]$ ' 
Certain members of these groups also posted Awjili materials on personal accounts, some of which they kindly allowed us to view, or on more general Berber groups, notably Multaqà šabāb wa banāt 'Amāzī $\gamma^{5}$.

In addition to providing new data on the language and its situation, this unusual corpus makes it possible to examine the process of language attrition. In this paper we will look at unexpected features of the phonology, grammar and vocabulary of the Facebook Awjila corpus, and we will discuss methodological issues around the use of social media for linguistic 'fieldwork'. While the materials used here have been made publicly visible by the users themselves, we have replaced personal names with X/ in order to preserve anonymity.

\section{Phonology and orthography}

Awjila Berber has some phonetic features that distinguish it from Arabic phonology, and some that distinguish it from the phonology of most other Berber varieties. Since the forum's members consistently use Arabic script, as frequently found in Saharan Berber online activity (Souag 2014), this poses some difficulties of transcription which must be addressed in order to interpret the data appropriately. In one case, it also confirms the continued presence -and suggests the incipient retreat- of a phoneme absent from local Arabic, /v/. Despite such orthographic issues, the forum data repeatedly confirms the reliability of Paradisi's transcriptions, including ones that are surprising in a comparative Berber perspective: القمت >alúğŏm> 'camel', اللوغم >alégmet> 'Friday', نـمـي >n>+>ámmī> 'of my paternal uncle', السوكم >ssûk>+>-i> 'at the

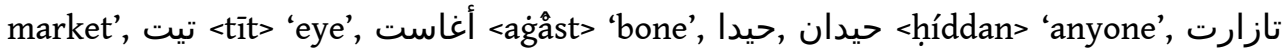
<tazârt> 'hand-mill'.

\subsection{Transcription}

ق is used to represent both /g/ and /q/, since in Libya, Ar. $q$ has shifted to /g/: قان gan 'there', يقيمه yəqqima 'he has remained'. Unlike local Arabic, Awjila Berber phonemically distinguishes $z$ from $z$; both are transcribed identically as j, eg: ابزاليم (ə)bzáalim ‘onion', ازوان (ə)ẓwàn 'palm trees’.

Word-internally, vowels are usually represented plene, but fairly often omitted, especially in unstressed closed syllables. Final $a$ can be written as any of 0,0, , l, eg:

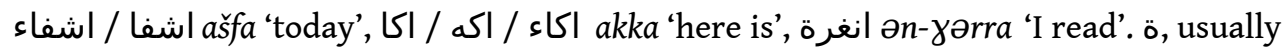
limited to obvious Arabic loans, may also be read t انطرة / ənțər-t 'leave it'.

Final $u$ is usually simply written with $g$, but (on nouns as well as verbs) is occasionally written with وا وa if it were an Arabic 3pl.m. perfective ending: قيلو, قيلوا gilu 'Jalu (oasis)'. او اديوا :əddiwa 'what?'

\subsection{Phonotactics}

In the middle of a three-consonant cluster, $x$ and $\gamma$ seem to vanish; cp. تامورت tamurt 'big locust', presumably < tamúrəy 'grasshoppers (coll.)' with f.sg. circumfix $t-. . .-t$, or:

طغاشكم العلا (1)

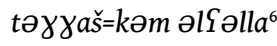


love:impf=DO.2sgf much

'I love you very much'

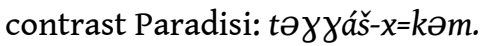

نك اشنت كا (2)

$n \partial k$ əšš

I know:1sg=D0.3sgm neg

'I don't know it.'

expected: əร̌šən- $x=t$.

\subsection{Representation of Awjila $v$}

Unlike most Berber languages, Awjili retains a reflex of Proto-Berber ${ }^{*} \beta$, transcribed $<v>$ by Paradisi. Arabic lacks this phoneme, and standard Arabic keyboards have no letter for it. In wordlists, $v$ is often indicated using Latin script inside or after the word, eg:

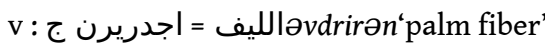

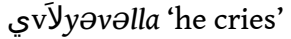

يvإِyovdid=a ( $r$ typed for $d)$ 'he stands'

Outside of the wordlists, however, it is normally just written as ف:

جفونس lažəvu=nnəs 'his hair'

إيجفين ižvin 'palm fiber'

افون افون 'avun 'rain'

One poster often transcribes it in wordlists with Latin $<g>$ or Arabic ق. Instances of Arabic $ق$ may be intended for $\dot{\imath}$, commonly used in Arabic to represent the phoneme $v$ but absent from standard keyboards. This explanation, however, does not account for attestations with the Latin letter $g$. Such cases perhaps suggest that, to this poster, the $v$ has a different phonetic value in certain contexts - perhaps de-labialised to $g$, or simply g:

İgavun 'rain'

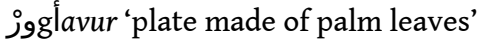

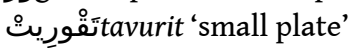

تقُوْرِتِ

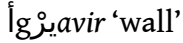

\section{Grammar}

\subsection{Nominals}

\subsubsection{Plurals}

Berber languages, like Arabic, have a complex system of plural formation. Much of the complexity recorded by Paradisi for Awjili seems to be intact: the few plural forms attested in this corpus mostly correspond to Paradisi's, eg:

أَمَدَ pl. مَدِنَ amədən pl. mədinən 'person'

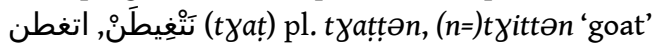




$$
\begin{aligned}
& \text { isəmpl.smiwən 'ear' } \\
& \text { ) قلازن إيسون }
\end{aligned}
$$

The regular feminine plural suffix -in is almost never written with a long vowel in the final syllable. This might suggest that it has merged with the masculine plural suffix ən. However, there are many other cases where (especially) long vowels in final closed syllables are not written, so this is probably merely orthographic, eg:

$$
\text { الدري الدريون . ədddriwin 'thorns'.? }
$$

At least one case is found of a noun which is written both with and without the -in suffix:

$$
\text { تقيليوين تقليون ,təgiliwin 'heads' }
$$

Most masculine nouns in Paradisi's material have a prefix $a$-in the singular that is dropped in the plural. This morphological pattern does not seem to be fully retained for all posters. We find several masculine plurals that retain the prefix $a$ - in the plural:

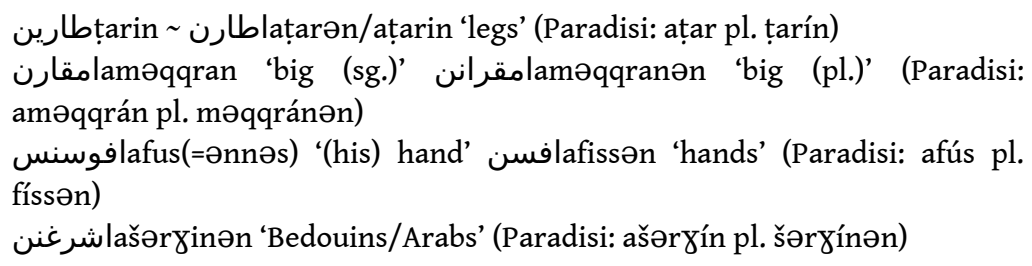

The suppletive plural to iwi '(my) son' in Paradisi's material is aməzzin. In the corpus this word has the broader meaning 'boys, children'. This word, which in morphology is not obviously plural, receives a masculine -ən suffix four times in our corpus:

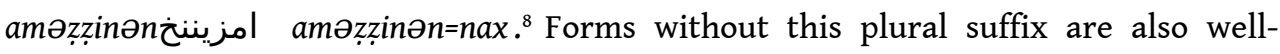
attested, eg: امزينكم aməẓ̇zin=nəkim.

At least one poster has back-formed a singular from the plural smiwən 'ears', using smiw rather than expected isəm.

\subsubsection{Genitive construction}

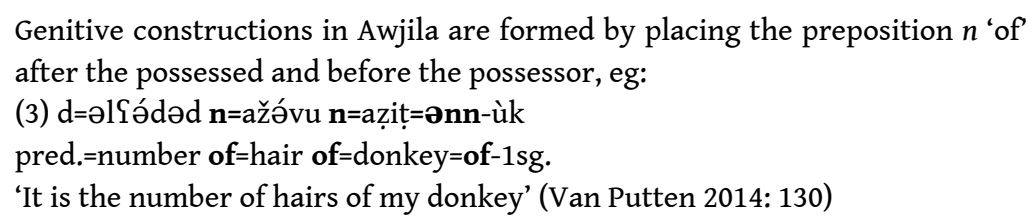

This preposition can take pronominal endings, and such pronominal possessives are cliticized to the noun they modify (as in aziț=ənn-ùk 'my donkey' above).

Libyan Arabic differs in this regard. Besides an analytic construction with the particle imt $\bar{a} S$, Arabic genitive constructions can be formed by the simple juxtaposition of two nouns:

(4) finžāl gahwa

cup coffee

'a cup of coffee' (Owens 1984: 83) 
The Facebook Awjila material has many examples of the original genitive constructions with the preposition $n$ 'of':

إيشن كا جلان نا ويلن س!! (5) (5)

$i$-ššən ka žlan $\boldsymbol{n}=$ awilən $X$

3-know neg words of=Awjilans $X$

'He doesn't know the language of the Awjilans, X!!'

including clearly original coinages, such as the following name suggested for a radio station:

حس انلاحرار اشالنخ (6)

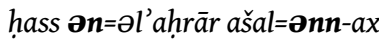

sound of=free(pl.) village $=$ of $-1 \mathrm{pl}$

'Sound of the Free, our town'

However, a significant number of genitive constructions instead use the Arabic syntax of simple juxtaposition:

دشفا اتشيخا البازين واقصوم اقاجط اشلنخ (7)

dašfa əčči- $x=a$ əlbazin $w=\boldsymbol{\text { Oqșum }}$ aqažit $a$ ašal=ənn- $a x$

today eat-1sg=res bazeen and=meat chicken village $=$ of $-1 \mathrm{pl}$

'Today I have eaten bazeen and chicken meat in/of our town.'

وايا يغلي اكصوم اتغطن مشكون (8)

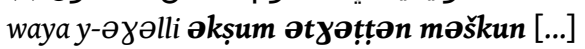

prox:ms3-want meat goats small [...]

'This one wants little goats' meat [...]'

Both in Awjili and in Arabic, pronominal possession is expressed by the suffixation of pronominal suffixes to the noun. The pronominal possessive suffixes are accordingly largely unaffected in this material, with the exception of rare instances of possible borrowing, such as -na in the following phrase:

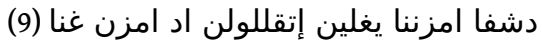

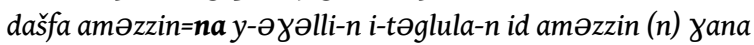

today boys=1pl 3-want-3pl 3-play.impf-3pl with boys (of) Ghana

'Today our boys (ie the Libyan football team) will be playing against the Ghana boys.'

\subsubsection{Quantification}

In previous data, kəra is attested only with the meanings 'thing, nothing'. One example in the present data confirms that kəra followed by a genitive can be used as an indefinite quantifier, like cognates elsewhere in Berber:

وكان اتغلييم كران انلحاجت تصوصميم كا (10)

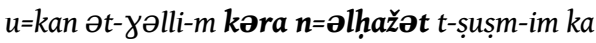

and=if 2-want-2pl some of=thing 2-be.quiet-2pl neg

'And if you pl. want something, don't be quiet.'

However, most instances of kəra in this corpus fulfill neither of these functions, instead serving to mark emphatic negation (see below).

In the Facebook corpus, a universal quantifier unattested in earlier material occurs very frequently: (بليل(ت) (presumably b(ə)lil-(ət)-). This quantifier is probably based on 
an Arabic form like Classical bi-kalilat- 'with the entirety of', but no documented attestations of it have been found in Arabic dialects. This quantifier is always followed by a pronominal suffix, usually Arabic but occasionally Berber, in one of two constructions.

In the commonest construction, the quantifier is feminine bəlil-(ə)t-, and the suffix is invariant 3sg. $\mathrm{m} / \mathrm{f}-a$ irrespective of the referent's person, number, and gender, yielding bəlilta.

س يشينا اجلانخ بليلتا الباين ونك نشينا ريحا (11)

$X y$-əššin=a əžlan=n-ax bəlilta əlbayən u=nək n-əššin=a riha

$X 3$-know=res words $=0 \mathrm{f}-1 \mathrm{pl}$ all clearly and=I $11-\mathrm{know}=$ res little

'X knows our language completely, clearly, and I know little.'

س يشينا بليلتا غير تزعيلا كا (12)

$X y$-ə̌̌šin $=a$ bəlilta yer $t$-əzYil=a ka

$X$ 3-know=res all just 2-get.angry=res neg

'X knows everything, just don't get angry.'

ربي يحفظ اماكم ايد اباكم بليلتا (13)

rəbbi y-əhfəd əmma-kim id abba-kim bəlilta

God 3-preserve mother-2plm and father-2plm all.

'May God preserve both your (pl.) mother and father.'

(14) بليلتا نغلي نشاي

bolilta $n$-yelli $n$-iša $=y(a)$

all 1-want 1-sleep=res

'All of us want to sleep.'

سماق يرول امزين بليلتا (15)

smag y-ərwəl aməzzin bəlilta

where 3-flee boys all

'Where have the boys all fled?'

However, we also find an alternative construction in which the quantifier remains masculine bəlil- and the pronominal suffix agrees with the referent. In most such cases, the suffix is Arabic in form:

حتي نك نشوت اندو قان نشوت بليلنا (16) hətta nək $n$-šu=t əndu gan $n$-šu-t bəlil-na even I 1-drink=DO.3sgm if there 1-drink=DO.3sgm all-1pl

'even I will drink it, if all of us drink it there'

الاوجله ايد قيلو كا تنفانا بليلكم ينيس س (17)

$X$ y-ənn=is bəlil-kəm $t$-ənfa- $n=a$ ka gilu id=ložəla

$X$ 3-say=IO.3sg all-2pl 2-benefit-pl=res Jalu and Awjila

'X says you all do not benefit Jalu and Awjila'

ما شاء الله بليلهم يتصينا (18)

mašallah bəlil-həm $y$-ətși-n=a

Mashallah all-3plm 3-laugh-3pl=res big

'Mashallah, they have all laughed.'

In this context, masculine plurals are sometimes found to take $3 \mathrm{pl}$. fem. agreement:

اشطافن بليلهن يرويعينا (19) اش)

əs̆țafənbəlil-hən $y$-ərw(i) $\{$-in=a

black.pl. all-3plf 3-be.afraid-3pl=res

'All the blacks are afraid'

امزيين الشرق ايد الغرب بليلهن يعاد الكفرتي (20)

aməzzin əššərq id=əlyərb bəlil-hən $y$-əYadd əlkəfrət=i 
boys east and=west all-3plf 3-go Kufra=loc

'All the boys/sons (of) the east and west went to Kufra'

In one case, which is grammatically anomalous for other reasons, the $1 \mathrm{pl}$. form is attested with a Berber rather than Arabic pronominal ending:

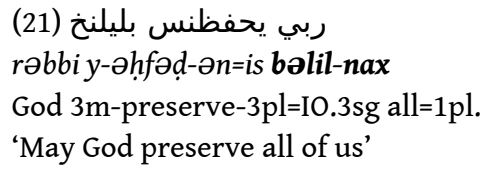

\subsubsection{Relativisation}

Awjili as described by Van Putten (2014:116-118) introduces relative clauses using a set of pre-modifier pronominal heads wa/wi/ta/ti (m.sg./m.pl./f.sg./f.pl.), or using the general relative pronouns wasa and ala. The former strategy is attested occasionally in this corpus:

جلان وي تنيتسه (22)

žlan wi $t-n i-t=i s=a$

words PMPH:mpl 2-say-2sg=IO.3sg=res

'the words you said'

وا راجان خير من وا تمنان (23)

wa raža-n xer mən wa təmənna-n

PMPH:msg wait-ptc better from PMPH:msg hope-ptc

'He who waits is better than he who hopes.' (a proverb)

More commonly, however, the formation of relative clauses in this corpus uses previously unattested relative markers - not wa etc., but rather wan:

وان غرصن اجلنخ ايد وان غلين المدن اجلانخ (24)

wan yar-sin əžlan=nn-ax id=wan yəlli-n $a=l m \partial d$-ən əžlan=nn-ax

rel to-3plm word=of- $1 \mathrm{pl}$ and=rel want-ptc fut=learn- $3 \mathrm{pl}$ words=of- $1 \mathrm{pl}$

'those who have our language/words and those who want to learn our

language/words'

وينطرانى امدنيسن وان نين الكفرت الوزينى (25)

$u=y$-ənter-an=a amədinn=nə-sin wan nni- $n$ əlkufrot $=i$ əlluz-in=a

and $=3$-abandoned-3pl=res people $=$ of $-3 \mathrm{plm}$ rel be.at $-3 \mathrm{pl}$ Kufra $=10 \mathrm{c}$

hungry-3pl=res

'and they have abandoned their people who are in Kufra hungry'

اغزر وان يني دفرنس (26)

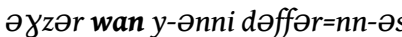

look:imp.2sg rel 3-be. at behind=of-3sg

'Look at the one who's behind him'

or, less often, win:

وين غارس اجلان يشرويت اجلانخ (27)

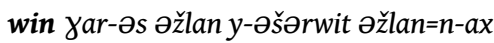

rel to-3sg words 3-speak words=of- $1 \mathrm{pl}$

'Let him who has the language/words speak our language/words.'

اجلان وين تشنت كا (28)

əžlan win $t$-əššən-t ka

words rel 2-know-2sg neg

'words that you don't know' 
There is no corpus-internal evidence that either of these markers show agreement. Reminiscent of the Siwi relative marker wən $(\mathrm{m} / \mathrm{pl})$, $\tan (\mathrm{f})$, this feature is obviously not a result of Arabic influence, but rather must indicate the existence of previously unattested dialect differentiation within Awjili.

Free relative clauses formed with mani 'who?' are not attested in Paradisi's corpus, but occur several times here:

ماني قان سيارة تنفايا يشكي للمجلس (29)

mani gan səyyarət $t$-ənfa=ya y-əški l=əlmažləs

who there car 3sgf-become.useful=res 3-leave to=council

'Whoever has a useful car should go to the council.'

ايغليين من يطفتي ويغليين من يطفتي امدن ينفيا ويروع الله (30)

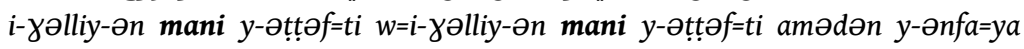

$u=y$-ərwəS əllah

3-want-3pl who take=D0.3sgm and=3-want-3pl who take=DO.3sgm man 3-

become.useful=res and=3-fear God

'They need someone to take charge of it, and they need the one who takes charge of it to be a person who is useful and fears God.'

\subsubsection{Prepositions}

A previously unattested locative preposition tan occurs several times in the corpus; context suggests that it means something like 'at, by, around':

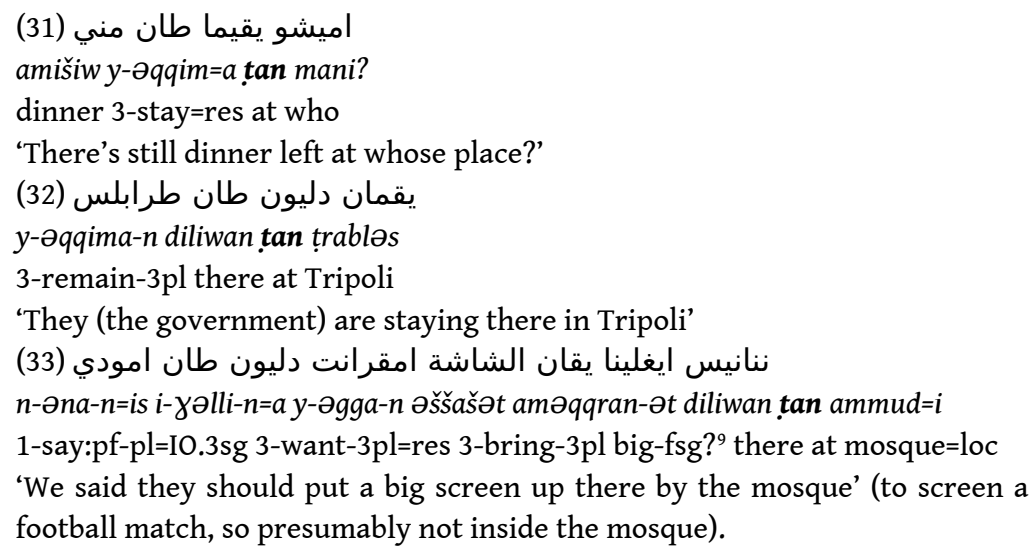

The etymology of this preposition is unclear, especially given the uncertainty in its meaning. The most attractive possibilities are ațar $n$ 'foot of', or uța $n$ 'under' (Van Putten 2014:133).

Other new prepositions, by contrast, are obvious Arabic loans. mən 'from' (already attested in Paradisi following agur 'near') is attested with unambiguously non-Arabic objects, both in the ablative sense:

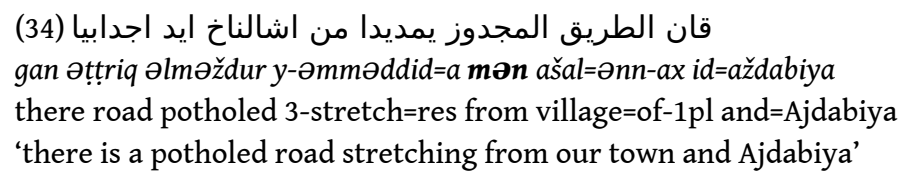

and as a comparative marker, eg in 23 or:

$$
\text { وكل ايوين يغلي ايوس اخير منهم اكل (35) }
$$


u=kull iwin y-əðəlli iwi-s axir mən-hum əkkull

and=each one 3-wants son-3sg better from-3plm all

'and each one wanted his own son to be the best of them all.'

However, the ablative sense is normally expressed by inherited s/syar/sar, while the comparative sense may also be expressed by genitive $2 n$ or the inherited ablative marker:

اسماق اوشندا سبنغازي نغ مصراته (36)

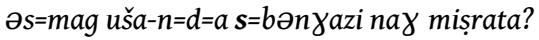

from=where come:pf-3pl=come=res from=Benghazi or Misrata

'Where did they come from, from Benghazi or Misrata?'

قان كراء اخير انمودي (37)

gan kəra axir $\boldsymbol{\theta}=a m m u d=i$

there neg better of $=$ mosque $=$ loc

'There is nothing better than in the mosque.'

به ايمين ازوان ارحم سغار الدخان (38)

bah imin əzwan ərhəm syar ədduxxan

fine water palms merciful/better from smoking

'fine, lagbi is more merciful/better than smoking.'

Arabic $f i$ 'in' is also frequently attested, at least once with a Berber noun, and once in combination with the inherited locative clitic $=i$ that normally expresses the same function:

نك ام البصيص في اشال العميان (39)

nək am əlbəșị fi ašal əl⿳amyan

I like one-eye in land blind

'I am like the one-eyed man in the land of the blind.'

ونغلي يقيم اجلاخ في الديستوري (40)

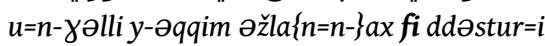

and=1-want 3-stay words=of- $1 \mathrm{pl}$ in constitution=loc

'and we want our language to be in the constitution'

يقماناكا في الفيس (41)

$y$-əqqima- $n=a$ ka fi lfes

3-stay-3pl=res neg in Facebook

'they have not remained on Facebook'

All attestations of $l=$ 'for' so far observed combine with Arabic objects, and hence may be code-switches; nevertheless, it occurs repeatedly:

نغلي اكليم للسواني (42)

$n$-yəlli akəllim $\mathbf{l}=$ əsswani

1 -want servant to=farm

'I want a servant for the farm.'

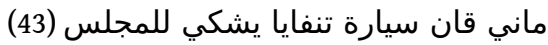

mani gan səyyarət $t$-ənfa=ya $y$-əški l=əlmažləs

who there car 3sgf-become.useful=res 3-leave to=council

'Whoever has a useful car should go to the council.'

Rarer loan prepositions in the corpus include wəst 'in the middle of', badal/bdəl 'instead of'. 


\subsubsection{Copula}

Traditional Awjili used the Berber copula marker d, sometimes retained in this data:

$$
\begin{aligned}
& \text { نك داويل!!! (44) } \\
& \text { nək } \boldsymbol{d}=\text { awil!!! } \\
& \text { I pred=Awjili } \\
& \text { 'I’m Awjili!!!' }
\end{aligned}
$$

However, the new data also seems to include null copulas, as in Arabic -this usage is notably common in insults:

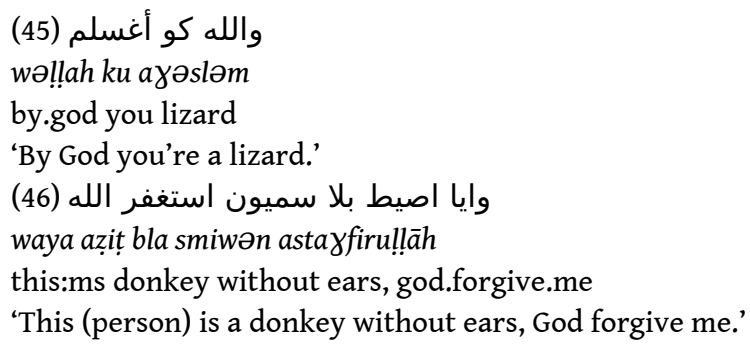

\subsection{Verbal morphology}

\subsubsection{Subject agreement}

The subject agreement in Awjili in the Facebook material is considerably different compared to Paradisi's material. Paradisi's Awjili has a fairly typical Berber agreement system. Facebook Awjili however has a very chaotic one, heavily influenced by dialectal Arabic prefix conjugation.

The complete PNG-marking of Awjili can be represented as follows (Van Putten 2014: 71):

\begin{tabular}{|l|l|l|l|}
\hline & $\mathbf{s g .}$ & & $\mathbf{p l .}$ \\
\hline $\mathbf{1}$ & $-x,-\gamma$ & & $n-$ \\
\hline $\mathbf{2}$ & $t-\ldots-t$ & $\mathbf{m}$ & $t-\ldots-$-im \\
\hline & & $\mathbf{f}$ & $t-\ldots-m \partial t$ \\
\hline $\mathbf{3 m}$ & $y-$ & & $-\partial n$ \\
\hline $\mathbf{3 f}$ & $t-$ & & $-n \partial t$ \\
\hline
\end{tabular}

TABLE 1. AWJILI PNG-MARKINg

Assuming that imperfect learners are likely to reduce the number of morphemes involved in this system, its most internally vulnerable aspect should be the gender distinctions made in the plural, since gender distinction in the plural statistically implies gender distinction in the singular (Greenberg 1963; Plank \& Schellinger 1997). 
This is, in fact, observed; many posters have, as in Siwi, lost the gender distinctions in plural agreement in favour of the former masculine plural forms.

However, the effects of interference are more significant. Eastern Libyan Arabic has a Maghrebi prefix conjugation, in which the historical 1pl. marker $n$ - has spread to the 1sg., and the 1pl. has been extended with the 3pl.m. marker - $u$ (Owens 1984: 104) although, unlike many Maghrebi dialects, it has retained gender distinctions in the plural:

\begin{tabular}{|l|l|l|}
\hline & sg. & pl. \\
\hline $\mathbf{1}$ & $n-$ & $n-\ldots-u,-\underline{a} w$ \\
\hline $\mathbf{2 m}$ & $t-$ & $n-\ldots-u,-\underline{a} w$ \\
\hline $\mathbf{2 f}$ & $t-\ldots-i,-a y$ & $t-\ldots-a n,-\underline{a n} n$ \\
\hline $\mathbf{3 m}$ & $y-$ & $y-\ldots-u,-\underline{a} w$ \\
\hline $\mathbf{3 f}$ & $t-$ & $y-\ldots-a n,-\underline{a} n$ \\
\hline
\end{tabular}

Table 2. Libyan prefix conjugation

Due to Afroasiatic common inheritance, 3m.sg. and 3f.sg. agree perfectly between Awjila Berber and Libyan Arabic, while 2sg./pl. and 1pl. overlap. Moreover, the Libyan 1sg. prefix is identical to the Awjili 1pl. prefix, while the Libyan f.pl. suffix is identical to the Awjili 3m.pl. suffix. In both languages, the prefixes of 2sg. and 3f.sg. are identical; the only difference is that in Awjili 2sg. takes an additional suffix - $t$, while in Arabic $2 \mathrm{~m} . s g .=3 \mathrm{f} . \mathrm{sg}$., and 2f.sg. takes a distinct suffix $-i$. This extensive overlap creates optimal conditions for interference, which in fact we find. For these posters, 1sg. and 1pl. are both often $n$-, and 2sg. and 3f.sg. are both often $t$ - as in Arabic -reducing the affixes to those shared across the two paradigms- while partial homophony has probably also encouraged the replacement of f.pl. forms with m.pl., notwithstanding the possible internal motivations discussed. Moreover, they have variably copied the identity within Arabic of the 2m.pl. and 3m.pl. suffixes. At the extreme (although no one poster consistently uses all of these innovations), this yields the following heavily restructured and simplified paradigm:

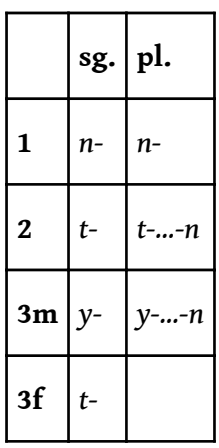


Table 3. Restructured Awjili PNG marking

Insofar as this is the result of interference, aspect might be expected to be relevant. In Arabic, the prefix conjugation is imperfective, while perfectives use a distinct suffix conjugation, in which the only overlap is 2 sg., and the only cross-linguistic equation that still applies is Libyan f.pl. = Awjili $3 \mathrm{~m} . \mathrm{pl}$. A priori, we might therefore expect interference to be stronger with imperfectives than with perfectives. However, no evidence for this has been observed. Perhaps this is because, whereas Arabic distinguishes aspect by agreement affix selection as well as by stem selection, Berber does so only by stem selection (except in the imperative or in stative verbs); aspect is thus not relevant to agreement affix selection in Berber.

\subsubsection{1st person marking}

Usually, the 1sg. marking is marked with the $n$ - prefix, as in Libyan Arabic:

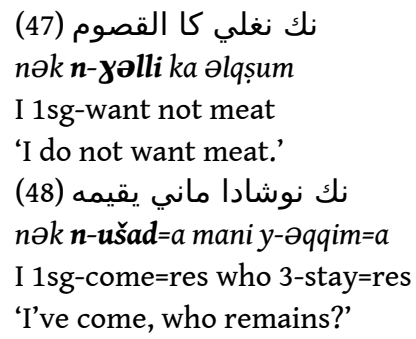

This creates systematic ambiguity with 1 pl., which remains $n$-:

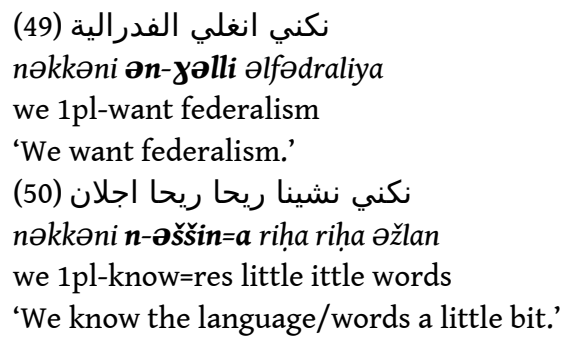

In some cases, however, the original 1 sg. suffix $-\gamma /-x$ is retained:

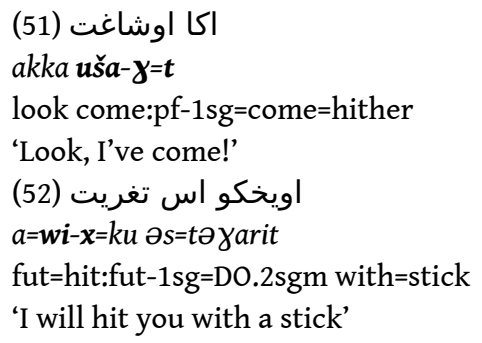

Occasionally we find double 1sg. marking: $n-\ldots-x$ :

نك نغليخكو كو تقيمى امقرنا اشالنخ (53)

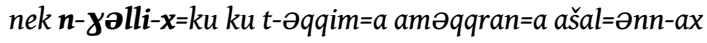
I 1-want-1sg=D0.2sgm you 2sgstay=res big=res village $=$ of $-1 \mathrm{pl}$ 'I want you to stay great, (oh) our village' نقيمخا سيمني نشنتا كا لعلا اجلان (54)

n-Oqqimi-x=a s=iman-i $n$-əššin=t=a lY əlla əžlan 
1-stay-1sg=res with=oneself-1sg 1-know=DO.3sgm=res many words

'I have stayed by myself, I don't know it a lot of words'

Posters occasionally seem to express the 1sg. with $-a$, previously attested only as a allomorph used when 1sg. is followed by an indirect object clitic (Van Putten 2014: 72):

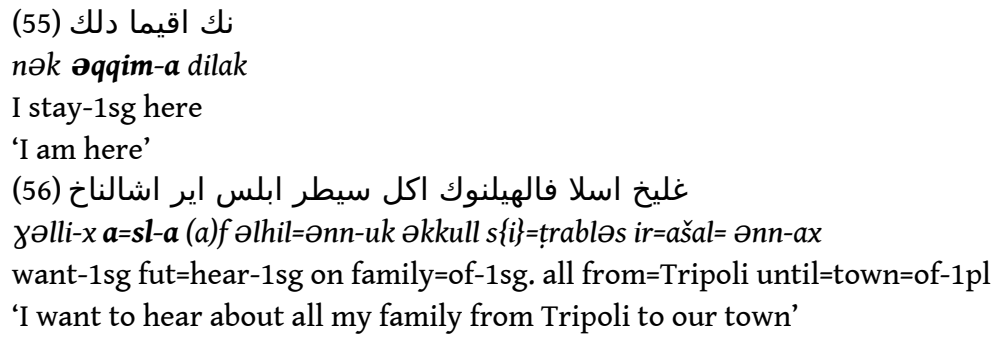

Once, we even find 3sg.m. marking for expected 1sg:

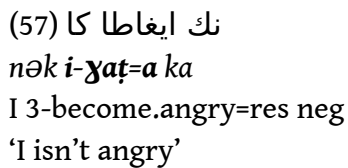

\subsubsection{2nd person marking}

The 2 sg. is often represented with only a $t$ - prefix, which makes it look identical to the 3sg.f. prefix.
س تزعيلا ناغ اديوا (58)

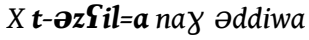
$\mathrm{X} 2$-become.angry=res or what
'X (name of male addressee), are you angry or what?'
س تشينا أرطانة كو ناغ أزديوا (59)
$X \boldsymbol{t}$-əššin $=\boldsymbol{a}$ Orțana ku nay $\partial \mathrm{z}=$ ddiwa?
$\mathrm{X}$ 2sg-know=res. jargon you or with=what?
'X, do you know the jargon or how much?'

In Paradisi's material, az-ddiwa means 'how much?' (litt. 'with what'); here, it might be understood as ddiwa 'what?', or as a question about how much Awjili the other person knows.

The original Berber marking $t-. . .-t$ is less commonly also still attested.

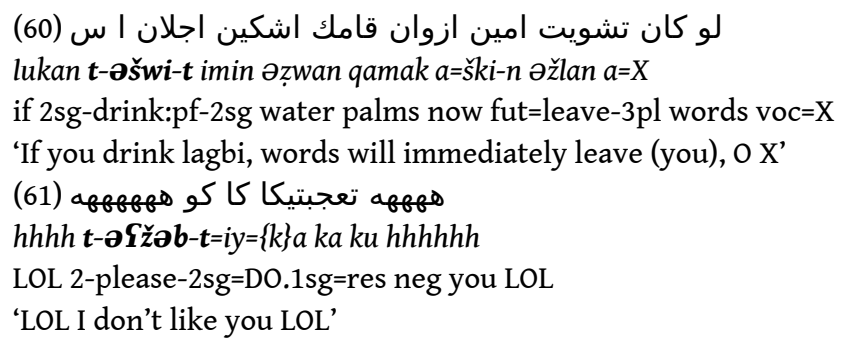

For 2pl.m. marking, the prefix is $t$ - as expected, but in some cases, this takes $-n$ rather than expected $-m$ :

تصبحينا علي خير (62)

t-Osboh-in=a Sla xer 
2-pass.morning-pl=res on good

'May you pass the morning in peace (ie "Good night")'

س ينيس بليلكم تنفانا كا قيلو ايد الاوجله (63)

$X y$-ən=is bəlil-kəm $\boldsymbol{t}$-Onfa-n=a ka gilu id=ložəla

$X$ 3-say=IO.3sg all-2plm 2-be.useful-3pl=res neg Jalu and= Awjila

'X said: You all don't benefit Jalu and Awjila.'

This looks like a calque of Arabic, in which the plural suffixes in 2pl. and 3pl. imperfective affixes happen to be identical. More commonly, the marking is as expected:

وكان اتغلييم كران انلحاجت تصوصميم كا (64)

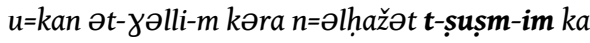
and=if 2-want-2pl some of=thing 2-be.quiet-2pl neg

'And if you pl. want something, don't be quiet.'

\subsubsection{3pl.m. marking}

3pl.m. is often represented with a circumfix $y-\ldots-. .-\partial n$, rather than the original - - $n$ attested in Paradisi's material. This parallels the situation in Siwi, also probably due to Arabic influence (Souag 2013:47).

مزين يغلن تغاريت (65)

[a]məzzin $\boldsymbol{y}$-əyəlli-n təyarit

children 3-want-3pl stick

'The kids want the stick.'

امقرانن يشننا كا الفيس بوك ايغليين من اشلمدسن (66) إ)

aməqqranən $\boldsymbol{y}$-əššən-(i)n=a ka əlfesbuk $i$ - $\gamma$ -

old.ones 3-know-3pl=res neg Facebook 3-know-3pl who 3-teach=IO.3pl

'The old people don't know Facebook, they need someone to teach them.'

غارس اباس اد اماس اد ناناس يشنينا اجلنخ (67)

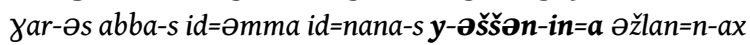

to-3sg father-3sg and=mother/brother-3sg and=grandmother= 3sg 3-

know-3pl=res language $=\mathrm{of}-1 \mathrm{pl}$

'He has his father and his mother/brother and his grandmother, they know

our language.'

However, the original form is also attested:

ابدسن ايد امدسن شوان ارقيلت (68)

abba-tsən id əmma-tsən šwa-n ərgilət

father-3pl and mother-3pl drink:pf-3pl hookah

'Their father and mother smoked (drank) the hookah.'

\subsubsection{Feminine plural marking}

Feminine plurals rarely occur in this corpus, but one of the few examples shows loss of feminine plural agreement:

اتغلي اتنيس مقنيون ينفنا كا (69)

ət-yəlli $(a=) t-n=i s(t) m \partial g n i w i n ~ y-\partial n f-i n=a k a$

3sgf-want (fut=)3sgf-say=IO.3sg women 3-become.useful-3pl=res neg

'She wants/ought to say that women are not useful.' 
To complement the more naturalistic data otherwise used, one author asked the group for paradigms, which two members kindly provided. One gave a full conservative paradigm, in the resultative ('has laughed'), whose only anomaly, an unexpected $v$ in 2f.pl., may just be a typographical error ( $m$ and $n$ are adjacent on the Arabic keyboard):

10

\begin{tabular}{|c|c|c|c|c|c|}
\hline & \multicolumn{2}{|l|}{ sg. } & & \multicolumn{2}{|l|}{ pl. } \\
\hline 1 & اطصيخا & əț̦i- $x=a$ & & | نتطصايا | & $n-\partial t ̦ s a=y a$ \\
\hline \multirow[t]{2}{*}{2} & تطصيتا & $t-\partial t ̦ ̦ i-t=a$ & $\mathrm{~m}$ & | تطصاما & $t-\partial t s a-m=a$ \\
\hline & & & $\mathrm{f}$ & | تطصيمنيتا | & $t-\partial t s ̦ i-m\{\{\} i t=a$ \\
\hline $3 \mathrm{~m}$ & يطصايا & $y$-əț̦a $a=y a$ & & | اطصانا | & Zț̦a-n=a \\
\hline $3 \mathrm{f}$ & تطصايا & $t-\partial t ̦ s a=y a$ & & | اطصانيتا | & əț̦sa-nit=a \\
\hline
\end{tabular}

Table 4. Elicited conservative paradigm

The other, however (for perfective 'laughed'), systematically lost feminine plural forms, despite maintaining the $1 \mathrm{sg} / \mathrm{pl}$ distinction and the $2 \mathrm{sg} / 3 \mathrm{f}$ distinction:

\begin{tabular}{|c|c|c|c|c|c|}
\hline & sg. & & & pl. & \\
\hline 1 & اطصا & $\partial t \underline{s} a$ & & انطصا & ən-ța \\
\hline 2 & اطصيت & $\partial t s ̦ i-t$ & $\mathrm{~m}$ & ايطصان & $i-t ̦ s a-n$ \\
\hline & & & $\mathrm{f}$ & $?$ & \\
\hline $3 \mathrm{~m}$ & اطصا & $i-t ̦ ̣ a$ & & ايطصان & $i-t ̦ s a-n$ \\
\hline $3 \mathrm{f}$ & تطصا & $t$-əțșa & & اطصان & $i-t ̦ s ̦ a-n$ \\
\hline
\end{tabular}

Table 5. Elicited paradigm with attrition ${ }^{11}$

\subsubsection{The subject relative form}

Like many Berber languages, there is a special type of verbal marking known as the Subject Relative form (often called 'participle' in the literature). This form is used when the head of the relative clause functions as the subject of the relative clause. In Awjila, it is morphologically identical to the 3pl.m. form -ən and does not agree in number or gender (Van Putten 2014: 73). It is attested several times in the Facebook Awjila corpus, eg in 23 or:

ارفعات فسينكيم وادعات ربينكيم س ايمق آم اموا علقينا (70) (7)

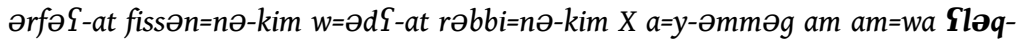

in $=a$ 
raise:imp-2plm hands=of-2plm and=pray:imp-2plm God=of-2plm X fut=3become like

ike=PMPH:ms hang:res-ptc=res

'raise your hands and pray to your God that X will become like this: hanged' (under a picture of $\mathrm{X}$ in a noose)

However, subject relative clauses in this corpus frequently instead use finite forms, eg 26 or:

ماقني وان يغلي يعمل سيس (71)

mag=i-nni wan $\boldsymbol{y}$-əyəlli $y$-əYm məl si-s?

where=3-be.at rel 3-want 3-act with-3sg

'Where are those who want to act on it?'

\subsubsection{Tense/aspect marking}

The Awjila language has a fairly complex, and markedly more extensive morphological tense/aspect system than Libyan Arabic. Morphologically, it distinguishes a imperative stem, a future stem (conventionally labelled future, but used for wider irrealis contexts), a perfective stem, an imperfective stem, and finally a resultative stem derived from the perfective. This differs significantly from Libyan Arabic, which only distinguishes an imperative, perfective and imperfective among finite forms, and uses a participle to indicate the resultative. The Libyan imperfective thus normally translates both the Awjili imperfective stem and the Awjili future stem.

In this corpus, the imperative, imperfective, perfective, and resultative are all wellpreserved, including irregular forms, as shown below:

\section{Imperative}

ياخ وياغد اقصوم الوغم ام افونس (72) yax u=ya yid əqșum aluyəm am afunas take:imp and=bring:imp meat camel like bull 'take (the money) and bring meat of the camel like the bull'

\section{Imperfective}

انغلي كراء ايوين اوساخ ايتاكر البارات(73)

әn-yəlli kəra iwin usax i-takər əlbarat

1-want neg one dirty 3sg.m.-steal:impf money

'I do not want someone dirty who steals money'

\section{Perfective}

بالك يوفان حنط القصوم (74)

balək $\boldsymbol{y}$-ufa-n hənț(a) əlqșum

maybe 3-find:pf-3pl bit meat

'Maybe they found a bit of meat'

\section{Resultative}

الله يرحمه وين يموينا وسلم ودرينا (75)

əllah $y$-ərhəm win $\boldsymbol{y}$-əmmuy-in=a w=səlləm wi ddər-in=a

God 3m-forgive rel 3m-die:res-3pl=res. and=preserve PMPH: mpl live-3pl=res

'God forgive those who have died, and preserve those who are (still) alive.' 
The weak point of the system under attrition is one for which one-to-one translation equivalence is missing: while the imperfective seems to be well-preserved, the future form seems to be unstable for many posters. However, it is replaced not by the imperfective but by the perfective, following the widespread Berber-internal trend (partially motivated by the $\breve{a} / \partial$ merger) to merge irrealis forms (the aorist and the imperative) with the perfective rather than calquing Arabic. ${ }^{12}$

The future stem and perfective stem are generally identical, but in Paradisi's material the future stem is always preceded by a future marker $a=$. In some cases, this is preserved:

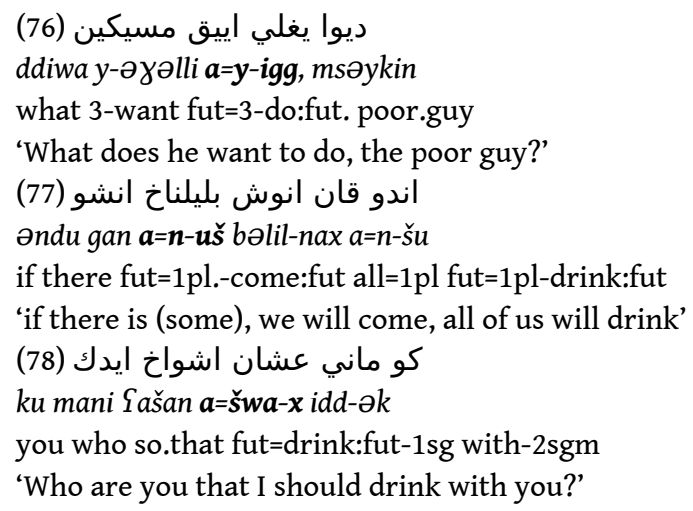

As these examples show, not only the prefix $a=$ but also the future stem are correctly used; for instance, šwa- only occurs in fut.1sg. and pf.3sg.m/3pl.m., and its pf.1sg. would be šwi-x. It thus seems that not only the prefix but also the stem form is retained correctly.

In many other cases, however, it is unambiguously absent, eg 82 or:

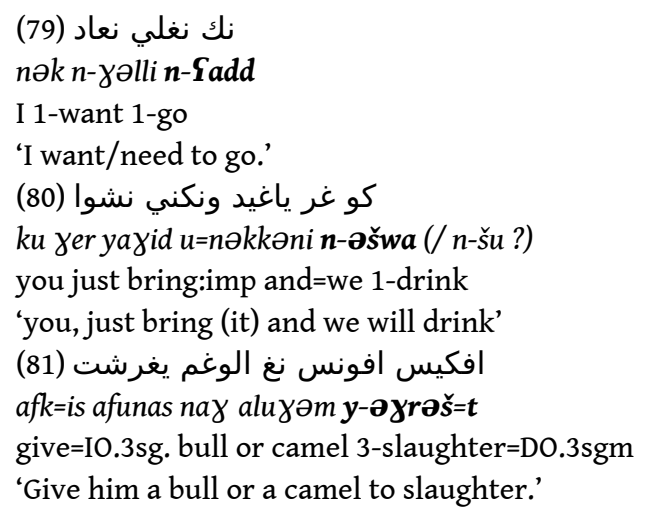

Insofar as the transcription allows us to distinguish the future stem from the perfective, it seems that the future is expressed in such cases with what in traditional Awjili would have been the perfective stem:

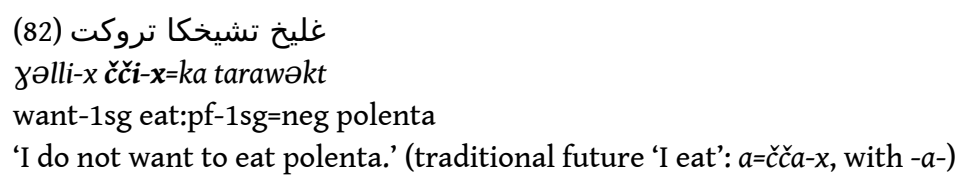




\subsubsection{Direct object clitics}

In Paradisi's materials (Van Putten 2014:109), the 3sg direct object clitics are as follows: $\mathrm{m}$. $=t($ res. $=t i=y a)$, f. $=t \partial t$ (res. $=t i t=a)$. In this corpus, however, 3sg.m. varies freely between $=t$ and $=t i$, with the latter rather frequent: thus the same poster describing the same cartoon on the same day wrote both:

$$
\begin{aligned}
& \text { يغلي يغرشتي (83) }
\end{aligned}
$$

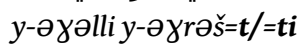

$$
\begin{aligned}
& \text { 3-want 3-slaughter=DO.3sgm } \\
& \text { 'He wants to kill him.' }
\end{aligned}
$$

The variant =ti occasionally also occurs with plural referents for expected =tən m., eg:

$$
\begin{aligned}
& \text { ننطرتي بليلهن (84) } \\
& \text { n-ənțər=ti bəlil-hən } \\
& \text { 1-leave=DO.3sgm all-3plf } \\
& \text { 'We will leave them all alone.' }
\end{aligned}
$$

\subsection{Negation}

Awjili is one of the few Berber languages to have reached Stage III of Jespersen's Cycle; negation is normally formed simply by suffixing the clitic ka to the head of the predicate, verbal or otherwise. In this corpus, only one synchronically unanalysable trace of the former preverbal negative was observed: the discourse particle ورشخ wəršš $\partial x<$ *wər ššən-əx 'I don't know'. However, in emphatic contexts the postverbal negator is often not ka but kəra, previously attested only with the meanings 'thing, nothing' (see above) except in a couple of problematic examples discussed in Van Putten (2014:220):

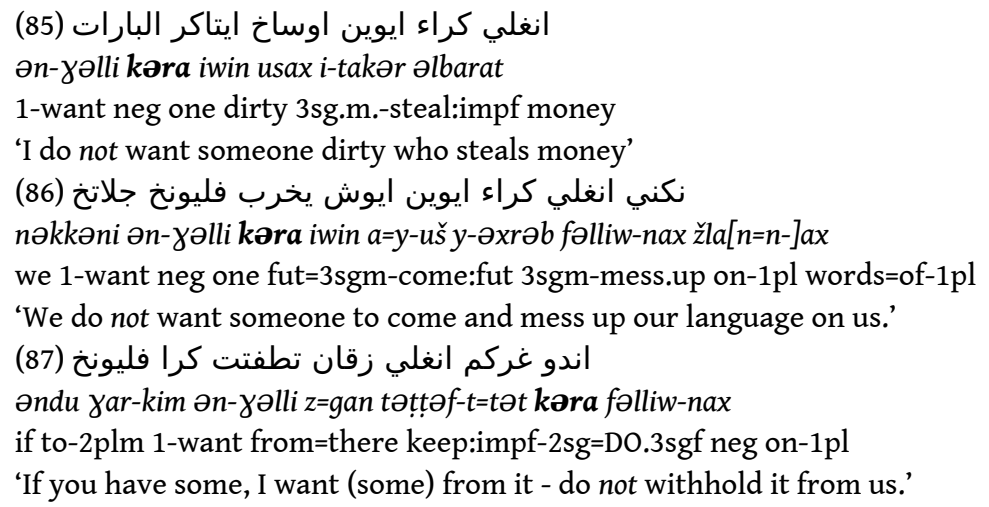

This construction is certainly an archaism, confirming that, as expected on general grounds, $k a$ is historically a shortening of $k \partial r a$.

In most Berber languages, postverbal negative particles do not combine with negative polarity items such as 'nothing', 'no one', 'never', 'not yet'. This seems to be true of the present corpus for 'nothing':

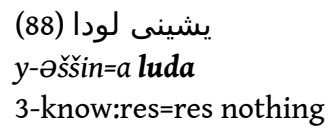


'He knows nothing.'

However, they do appear to combine here with 'no one / anyone', depending on the exact translation of the following:

غارس كراء حدا يشلمديس (89)

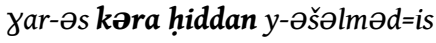

to-3sg neg anyone 3sgm-teach=IO.3sg

'She has no one to teach her.' (or: 'Doesn't she have anyone to teach her?')

قان كا حدا أشفا ناغ اديوا (90)

gan ka hiddan ašfa nay əddiwa?

there neg anyone today or what

'Is there no one there today, or what?'

\section{New lexical data}

While the new material provides a substantial number of previously unattested words, most are Arabic loans straightforwardly corresponding to modern Libyan forms and thus of little historical interest. Nevertheless, some stand out.

\subsection{Words with Berber cognates}

The following previously unattested forms are of clear Berber origin:

\section{اشوفlašuf 'wadi'}

The vowel in this word shows unexplained variation across Berber: Zenatic suf (eg Mzab, Delheure 1984) versus Middle Atlas Berber, Tashelhiyt, Kabyle asif (Oussikoum 2013; Sabir 2010: s.v. río; Dallet 1982). ${ }^{13}$ Apparently, Awjila aligns with Zenatic in this respect, despite having preserved the prefix.

\section{انينات اininat 'trivet-stones'}

Cp. Ouargli inni 'pierre du foyer' (Delheure 1987); the plural suffix -at is Arabic.

\section{القصوم}

Paradisi gives ksúm, but for reasons unknown, in the Facebook corpus, this word almost always has the Arabic article, and the first two consonants are usually emphatic (but contrast ex. 7, 8). This can perhaps be explained as an "expressive" formation of the word ksúm: for expressive formations, Berber occasionally introduces unetymological consonants into Berber words which are otherwise almost exclusively restricted to Arabic loanwords (Kossmann 2013: 199), and the resulting expressive words sometimes replace the unmarked words from which they were originally derived.

\section{تيليمتtillimt 'yarn'}

Presumably a deverbal noun from əlləm'spin', attested in Paradisi.

\section{lotttigən 'partly ripe dates' (طايبةطقرةبهبلح)}

Cf. Siwi atțeg 'half-ripe date' (Naumann ms), Ouargli utțig 'type of date, half-ripe date'.

\section{توتيقى $t$-utig=a 'to put on one's head'}

Cf. Middle Atlas Berber aty 'id.' Context:

ياريت تيجيري توتيقى (91) yarayt tižiri t-utig=a 
if.only rope 3sgf-put.on.head=res

'If only the rope would be around (lit. on) his head' (a wish to hang a murderer)

labu-fiddən 'locust (sp.)'

This seems to combine the Arabic prefix abu- 'possessor of (m.)' (widely borrowed into Berber) with the Berber noun fiddən 'knees'.

\section{Neologisms}

Alongside these, we observe some neologisms; the pan-Berber creation تاقرولا tagrawla 'revolution' occurs more than once, yielding تقراولين təgrawliyən 'revolutionaries', and in one case azul fəllawən 'greetings' is used. A more local creation, presumably originally used as cryptic language, also reflects recent history: اقاجط امقران aqažit aməqqran 'the big rooster = Gaddafi'. A particularly playful neologism, used only once in the corpus, is قلازنيسم qlazənism 'lies-ism', with what appears to be a borrowed English morpheme attached to an Awjili stem.

\subsection{Words of uncertain etymology}

A number of forms in this corpus have no known cognates. Some of these may be of Berber origin, while others might be loans from not yet identified sources:

ابوزي abuzi 'large ant'

asəlhu 'food sp. made from dates, nuts, flour, and oil'

aviriw / afiriw 'feed trough made from a split palm trunk'

امناشرق əmnašrəq/g 'Isha' (prayer time at the start of the night)

mžawən 'nearly ripe dates'

qروز وجاون qruz 'middle of the house (atrium?)'

Etfegi> ətfəggi 'palm orchard'

təmayalt 'bad-quality dates'

təbəklilt 'palm spathe'

تملكيمت təməlkimt 'bird sp.'

təs(ə)q/gut, pl. -in 'braid'

تيميكورت timikurt 'furrow (for planting seeds)'

v : vadrirən 'palm fiber'. This resembles the verb res. 3sg.m. yəvrúr=a 3pl.m. vrirín= $a$ 'to be fetilized (a palm)', but if linked, the expected mening would be 'pollen' rather than 'palm fiber' (ليف).

الششي ,شيش ,ششي (әš)̌̌ǐšši '(grilled) meat'. This seems to be onomatopoeic, representing the hissing of meat as it grills; cf. Siwi jiji 'piece of meat (baby talk)' (Souag, field data).

\subsection{Arabic loans}

While most Arabic loans are straightforward reflexes of their modern Libyan counterparts, a few show features unexpected for the region and are worthy of specific notice: 
ألفيت (a)lafit 'well-being'. The loss of $S$ in this word suggests that it was borrowed from Arabic al-Săfiyah at a relatively early date, before pharyngeals became well-established in Awjila (Van Putten \& Benkato fthc.).

aḥ(əm)mas 'friend'. If this derives from Arabic hamās 'zeal', the semantic shift is obscure.

تحبيت təhəhəbbit 'heart'. Presumably related to Arabic habbah 'grain', or less probably to hubb 'love'; the semantic shift is unexpected in either case.

تحاديت təhaditt 'bracelet', presumably from Arabic hadid 'iron', but with unexpected semantics.

تخاتيمت təxatimt 'ring'. This otherwise unproblematic loan from Arabic xātam exemplifies the regular sound change $\partial>i$, previously attested only in Berber vocabulary (cf. Van Putten 2013: 239).

أَسْرَاوِيلْ (a?/ə?)srawil 'trousers (sg.)'. Like Siwi srawilən, this word must have been borrowed from sarāwill, obsolete as a singular, before the singular form sirwāl became dominant, cf. Souag (2013: 61).

ستى sətti 'six'. Like Siwi sətti, this word seems to show an unexpected $-i$ in place of Classical -ah. The $s$ could in principle represent $a$, but in that case one would expect a transcription ستة.

اسميتنس Arabic smayya only means 'namesake', though the appropriate sense is well-attested elsewhere, eg Moroccan smiya (Harrell 1966), Siwi ssməyyət.

\subsection{Phatic speech}

Greetings and polite phrases are frequently given short shrift in descriptive materials oriented towards the needs of academic linguists, but are crucial for learning and revitalisation. The Facebook data, unlike Paradisi, is rich in such forms. These are often borrowed as wholes from Arabic, but exceptions include:

a=sal-ax fəllikim 'greetings' (lit. 'I greet you')

الحالنكيم ديوا ,حالنكم دي, الحانكم دي الحالنكيم ادي .

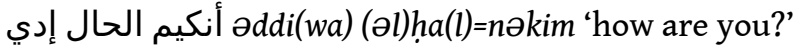

نلهيل حال ديل

'yak (a)lafit əmri-t 'you are well, I hope?’

يازن العقبت ,اليازن عقبة ,اليازن عقبة Sagbət (əl)yazən 'many happy returns!' (lit. 'returns next year!'), used on festivals

qqim s=(a)lafit, pl. addr. سلافيت قيمات qqimat s=(a)lafit 'goodbye' (lit. 'stay well')

lakka əd=badri ay=uma 'It's still early, brother'

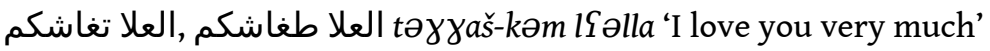

\section{Methodological issues}

The corpus being used here poses a number of difficulties related to its nature as the proceedings of a social media forum. Such difficulties are in many cases relevant not 
only to this specific study, but to the use of social media corpora in linguistics more generally.

\subsection{Limitations of the corpus}

The corpus examined here is not an ideal data source. The lack of a conventionalized spelling of Awjili, and the neutralisation of some phonemic contrasts in the Arabic transcription used, creates analytical difficulties, especially since there is no video or audio. Transcriptions are thus approximate, reducing the usefulness of any new vocabulary gleaned.

More significantly, the people most likely to be using Facebook -literate, younger, relatively affluent, frequently communicating with outsiders- are almost by definition the group least likely to represent traditional language use. A fieldworker on the ground would prioritise working with the elderly non-Facebook-users whom these groups' members identify as the best speakers, as in the following quote:

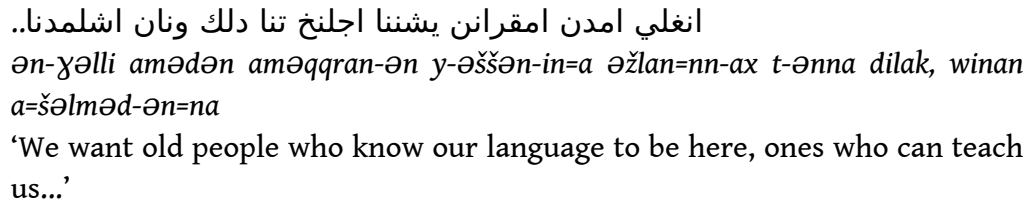

reply:

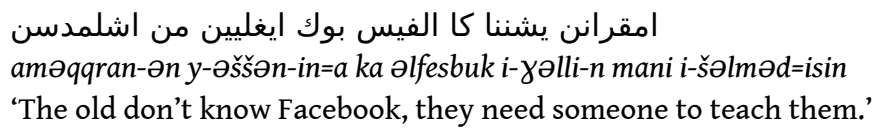

Without such fieldwork, it is hard to determine whether any given unexpected form represents a previously undocumented aspect of traditional Awjili, or just an artefact of imperfect language acquisition among younger Arabic-dominant speakers. For vocabulary, a touchstone is available -non-Arabic forms are unlikely to be new- but for grammar, the distinction is often impossible to draw. At most, it is possible to determine which of the posters diverges most from traditional grammar, and examine the inter-poster distribution of such forms.

\subsection{Advantages of the corpus}

Despite its limitations, material gathered online from social media has one advantage over more conventional fieldwork. Publicly viewable Facebook forums provide a large corpus of fairly naturally produced data, produced not for linguists' consumption but for communication with other posters. The "observer's paradox" (Labov 1972: 209) refers to the paradoxical situation where a researcher observes speakers in order to learn how they use language when they are not being observed. In the study of Facebook language usage, this paradox is circumvented, since the researcher is not explicitly present during the interaction (by the time one author joined the group and announced his presence, most postings had already been made).

In writing, speakers typically have more time to plan their language production than in spontaneous speech, affecting the results. The written language production on these Facebook groups, however, is much less planned than that of 'official' written media. 
The text produced consists largely of conversations, and the presence of typos and vacillations in spelling even within a single sentence suggests that the posters are paying relatively little attention to form. This same conversational tone is also seen in the occasional Arabic messages on the Ašal=ənnax page, which are usually written in Libyan Arabic, not Modern Standard Arabic.

Apart from its direct advantages, this corpus constitutes an endogenous effort at language revitalisation, increasing the unfortunately slim chances that this language will continue to be spoken long enough for a better corpus to be created. Since intergenerational transmission seems to have ceased for long enough that many young people no longer speak it, and that those who do speak it rate their own abilities as rather poor, these speakers' project of reviving Awjili poses challenges. Given that Libya has no effective central government at the moment, a government-led top-down approach to language preservation and promotion is currently impossible. Even if such a government were to emerge, there is no guarantee that it would provide effective support for minority languages. The group Ašal=ənnax exemplifies a 'do-it-yourself' alternative: an attempt at bottom-up revitalisation, taking advantage of new social media without waiting for state intervention. Such initiatives, many of which have emerged in post-revolutionary Libya, require nothing more from the state than the freedom to post without fear.

It remains to be seen whether such bottom-up revitalisation efforts will have any effect, although at the very least they extend the language's use to a new domain. As Wright (2007: 171) point out, "there is no agreed approach to the preservation of languages that is is not nation building on a smaller scale and little successful LPLP [Language Policy \& Language Planning] outside that framework." However, the social media tools available have changed drastically even since 2007, and new approaches remain to be tested.

\subsection{Purpose and political context of the corpus}

It is remarkable that the corpus being studied exists at all. The members all seem more fluent in Arabic than in Awjili, and certainly more accustomed to writing the former. In large part, their decision to write in Awjili here reflects a desire to learn the language better, as seen in the introduction. This desire may well have existed earlier as part of a general interest in preserving local heritage, as suggested by remarks such as:

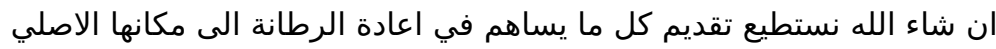

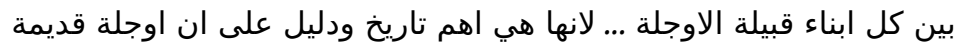

$$
\begin{aligned}
& \text { جدا|||| }
\end{aligned}
$$
ancient.'

However, understanding its emergence into the public domain requires examination of the wider ideological context.

In accordance with his version of pan-Arabism, Gaddafi marginalised Libya's minority languages. Not only was the use of Berber discouraged, but its existence was actively denied (Kohl 2014: 5). While the revolution against Gaddafi's government was initially most prominent in the eastern half of the country, opposition to his monocultural 
policy quickly helped rally Berber communities in the northwest against him. The important role played by Amazigh activists within the revolution was made conspicuous first by bilingual YouTube videos in which town assemblies proclaimed allegiance to the rebels, and later by Berber broadcasts on a rebel satellite channel (Lībyā al-'Ahrār). The expression of linguistic diversity was thus deployed as a means of demonstrating commitment to the anti-Gaddafi cause. It has been paralleled at the popular level by extensive new minority language expression on digital media such as YouTube and Facebook, usually combined -as here- with expressions of anti-Gaddafi political opinion.

After their victory in late 2011, differences among the former rebels would become increasingly prominent, finally breaking out into small-scale war in 2014. As of the time of writing (early 2015), Libya has two competing governments both claiming de jure legitimacy, coexisting with many de facto sovereign militias. Since mid-2014, Berber areas of the northwest have sided with the General National Congress, while the east is dominated by the Council of Deputies. One may assume that this change in the political context has also changed the semiotic value of public displays of Berber identity. If so, it is striking that the rate of posting on this group slowed to a crawl after mid-2014, with just four new posts in the course of six months. However, the posts in question offer no direct indications of the cause of this slowdown, which might simply be connected to Libya's increasingly frequent power outages.

\section{Conclusions}

Despite major difficulties, this corpus significantly supplements our knowledge of Awjili. It not only furnishes a number of previously unattested lexical items, including a couple of dozen of non-Arabic origin, but also makes it possible to describe the grammar of the language as used in an informal, conversational, multi-speaker context very different from that reflected by Paradisi's texts.

Its contributions to our knowledge of Awjili grammar can be divided into two classes: inherited constructions coincidentally absent from previous materials, new constructions resulting from imperfect learning alone, and new constructions resulting from the impact of Arabic. Inherited ones include 3sg.m. direct object clitic =ti, relativisers wan/win, locative tan, negator and quantifier kəra, and probably the usage of mani 'who?' to form free relative clauses. Imperfect learning is probably responsible for the regularisation of some plurals and the loss of feminine plural agreement, and perhaps for the incipient loss of the aorist. The impact of Arabic in these posters' grammar, however -already significant in traditional Awjili- is staggering: genitive formation by simple juxtaposition, sporadic usage of Arabic pronominal possessives and locative prepositions, a universal quantifier bəlil- together with its agreement suffixes, extensive reworking of verbal agreement affixes, and incipient loss of the participle and the predicative marker. The reworking of verbal agreement is particularly remarkable, insofar as bound inflectional morphology is normally one of the least vulnerable domains to external influence (Moravcsik 1978).

Even the best corpus of Facebook postings is no substitute for hearing the language spoken. Nevertheless, in situations where fieldwork is effectively impossible, due attention to comparative data can make such materials useful even for quite poorly 
documented languages, revealing new aspects of language use and suggesting avenues for future research in the event of a change in the situation.

\section{BIBLIOGRAPHY}

Al-Rumi A. (2009). "Libyan Berbers struggle to assert their identity online”, Arab Media \& Society (Spring, 2009). URL: http://arabmediasociety.com/articles/downloads/ 20090506151750_AMS8_Aisha_al-Rumi.pdf.

Central Intelligence Agency (2013). The World Factbook 2013-14. Washington, DC: Central Intelligence Agency.

Dallet J.-M. (1982). Dictionnaire kabyle-français. Parler des At Mangellat, Algérie. Paris: SELAF.

Delheure J. (1984). Ağraw n yiwalen tumz̧abt $t$-tfransist / Dictionnaire mozabite-français. Paris: SELAF.

Delheure, J. (1987). Agerraw $n$ iwalen teggargarent-tarumit / Dictionnaire ouargli-français. Paris: SELAF.

Fishman J. A. (1991). Reversing language shift, Clevedon, UK, Multilingual Matters Ltd.

Greenberg Joseph H. (1963). "Some Universals of Grammar with Particular Reference to the Order of Meaningful Elements”, in J.H. Greenberg (ed.) Universals of Human Language. Cambridge, Mass: MIT Press, 73-113.

Harrell R. (1966). A dictionary of Moroccan Arabic: Arabic-English. Washington, DC: Georgetown University.

Heath J. (2006). Dictionnaire touareg du Mali. Tamachek-anglais-français. Paris: Karthala.

Joffe G. (2014). "Minorities in the new Libya”, in M. Ennaji (ed.) Multiculturalism and Democracy in North Africa Aftermath of the Arab Spring. Abingdon: Routledge.

Kohl I. (2014). “Libya's ‘Major Minorities’. Berber, Tuareg and Tebu: Multiple Narratives of Citizenship, Language and Border Control”, Middle East Critique 23:4: 1-16.

Kossmann M. (1999). Essai sur la phonologie du proto-berbère. Köln: Rüdiger Köppe.

Kossmann M. (2005). Berber Loanwords in Hausa. (Berber Studies v. 12). Köln: Rüdiger Köppe.

Labov W. (1972). Sociolinguistic Patterns. Philadelphia: Uni-versity of Pennsylvania.

Moravcsik E. (1978). "Universals of language contact", in J.H. Greenberg (ed.) Universals of Human Language. Stanford: Stanford University Press, 94-122.

Müller F. (1827). "Vocabulaire du langage des habitants -d'Audjelah”, in J.-R. Pacho (ed.) Relation d'un voyage dans la Marmarique, la Cyrénaïque, et les Oasis d'Audjelah et de Maradèh, accompagnée de Cartes géographiques et topographique, et de Planches, représentant les Monuments de ces contrées. Paris: Didot, 319-352.

Oussikoum B. (2013). Dictionnaire Amazighe-Français. Le parler des Ayt Wirra. Moyen Atlas Maroc. Rabat: IRCAM. 
Owens J. (1984). A Short Reference Grammar of Eastern Libyan Arabic. Wiesbaden: Otto Harrassowitz.

Paradisi U. (1960). “Il berbero di Augila, Materiale lessicale”, Rivista degli Studi Orientali 35: 157177.

Paradisi U. (1961). “Testi berberi di Augila (Cirenaica)", Annali dell'Istituto Universitario Orientale di Napoli 10: 79-91.

Paradisi U. (1963). “Il linguaggio berbero di El-Fóqăha (Fezzân). Testi e materiale lessicale”, Annali. Nuova Serie 13: 93-126.

Plank F. \& Schellinger W. (1997). “The Uneven Distribution of Genders over Numbers: Greenberg Nos. 37 and 45", Linguistic Typology 1: 53-101.

Putten M. van. (2013). "Some Notes on the Development of Awjila Berber Vowels", Nordic Journal of African Studies 22(4) : 236-255.

Putten M. van. (2014). A Grammar of Awjila Berber (Libya) Based on Umberto Paradisi's Work (Berber Studies v. 41). Köln: Rüdiger Köppe.

Putten M. van. (2015). "Reflexes of the Proto-Berber glottal stop in Nefusa and Ghadames". Wiener Zeitschrift für die Kunde des Morgenlandes 105: 303-314.

Putten M. van. \& Benkato A. (fthc.). “The Arabic Strata in Awjila Berber”, in A. Al-Jallad (ed.) Arabic in Context. Leiden \& Boston: Brill.

Sabir A. (2010). Taknarit. Diccionario Español - Amasigh, Amasigh - Español. Rabat: Imprimerie Al Maarif Al-Jadida.

Souag L. (2013). Berber and Arabic in Siwa (Egypt). A Study in Linguistic Contact. (Berber Studies v. 37). Köln: Rüdiger Köppe.

Souag L. (2014). “Writing 'Shelha' in new media: Emergent non-Arabic literacy in Southwestern Algeria”, in M. Mumin and K. Versteegh (eds.), The Arabic Script in Africa: Studies on the Usage of a Writing System. Leiden: Brill, 91-104.

Wright S. (2007). "Language policy and language planning", in C. Llamas, L. Mullany \& P. Stockwell (eds.) The Routledge Companion to Sociolinguistics. London \& New York: Routledge, 164-172.

\section{NOTES}

1. We would like to thank Adam Benkato for providing information about Eastern Libyan Arabic from his fieldwork, elucidating some region--specific loanwords in the corpus. We also thank the Awjili-speaking members of these groups, and in particular those who took the time to answer our questions and allowed us to join them, for their generosity.

2. URL: https://www.facebook.com/groups/319672314747872/, viewed 18 February 2014 - 28 February 2015. At the time of writing, there were approximately 1200 Facebook messages written in Awjili Berber. Most messages are single sentences. Some of the messages are slightly longer paragraphs of text or wordlists.

3. The phonemic representation of the Awjili text is based on the analysis of the phonology of Paradisi's material as presented in Van Putten (2014).

4. URL: https://www.facebook.com/AmazyghAwjltTmazyghNTnyry/, viewed 18 February 2014 28 February 2015. 
5. URL: https://www.facebook.com/groups/group2alamazeg/, viewed 18 February 2014 - 28 February 2015.

6. In this paper, we mostly follow the glossing conventions used in Van Putten (2014). However, which stem a verb belongs to is marked only when unambiguous. Moreover, in this corpus $y$-is used for 3pl. as well as 3sg.m., and hence is glossed 3-; n- now stands for both 1sg and 1pl, and hence is glossed 1-; and the old 3pl.m. -ən no longer marks gender, and hence is glossed 3pl.

7. It is especially striking that word-final long vowels in closed syllables are not written. In Paradisi's material, such final syllables are always transcribed as accented. This might suggest Awjila has undergone an accent shift, or, more likely, that Paradisi misheard vowels as accented in this context, as he seems to have done for Zwara Berber (Van Putten 2014: 50).

8. aməzzin=nax would be the expected form if it did not have a final -ən; the possessive clitics in Awjila, while normally starting with =ənn start with $\mathrm{n}$ with following a noun that ends in $n$ (Van Putten 2014: 115).

9. This looks like a f.sg. stative ending, unexpectedly attached to the m.sg. adjective rather than to the stative verb from which it derives.

10. This gives a complete paradigm of the resultative forms of verbs with a final variable vowel, from which the perfective paradigm can be deduced. In previous material the 1pl. and 2pl.f. were unattested (Van Putten 2014: 75).

11. This paradigm is perhaps easier to understand as an imperfective, e.g. ițəșsa, ənțəșșa, ițəșsan, but it is equated by the informant as being equivalent to the Arabic perfective paradigm of dahika 'to laugh'.

12. See, for example, Siwi (Souag 2013: 183).

13. For a discussion, and a proposed historical explanation of this variation see Van Putten (2015).

\section{ABSTRACTS}

Awjila Berber is a highly endangered Berber variety spoken in eastern Libya. The minimal material available on it reveals that the language is in some respects very archaic and in others grammatically unique, and as such is of particular comparative and historical interest. Fieldwork has been impossible for decades due to the political situation. Recently, however, several inhabitants of Awjila have set up a Facebook group Ašal=ənnax ("our village"), posting largely in Awjili. Analysis of this partly conversational corpus makes it possible to extend our knowledge of the language, yielding unattested words and constructions. Examination of its grammatical features also reveals that these posters' usage is heavily influenced by Arabic, showing language attrition absent from earlier data; even subject-verb agreement has been extensively reworked. In both respects, this study casts light upon the uses and limits of social media as a source of linguistic material.

Attrition et renouveau dans le berbère Awjila. Les messages Facebook comme nouvelle source de données pour une langue berbère en voie de disparition

Le berbère d'Awjila est une langue de l'est de la Libye qui est en danger de disparition. Les rares données disponibles indiquent que cette langue a des traits très conservateurs et d'autres qui sont uniques dans le cadre des langues berbères. Elle est alors d'un intérêt exceptionnel pour les études comparatives et historiques. Pour des raisons politiques, aucune recherche sur le terrain 
n'a été possible depuis plusieurs décennies. Or plusieurs citoyens d'Awjila ont récemment créé un groupe sur Facebook, Ašal=ənnax («notre village»), où ils écrivent en awjili. L'analyse de ce corpus, en partie conversationnel, nous permet d'élargir notre connaissance de cette langue et fournit des mots et des constructions inconnus auparavant. L'étude de ses traits grammaticaux révèle une grande influence arabe sur leur usage, et montre un degré d'attrition qui ne se trouve pas dans les anciennes données; y compris la transformation de l'accord du verbe avec le sujet. Ces résultats aident à mieux comprendre l'utilité et les limites des médias sociaux comme source de données linguistiques.

\section{INDEX}

Mots-clés: Awjila, Berbère, médias sociaux, Facebook, attrition des langues, revitalisation des langues, contact des langues, Libye, langues en danger

Keywords: Awjila, Berber, social media, Facebook, language attrition, language revival, language contact, Libya, language endangerment

\section{AUTHORS}

\section{MARIJN VAN PUTTEN}

Leiden University

LAMEEN SOUAG

LACITO - CNRS / Paris-3 / INALCO 